\title{
Herbal medicines in Brazil: pharmacokinetic profile and potential herb-drug interactions
}

\author{
Andre L. D. A. Mazzari and Jose M. Prieto* \\ Department of Pharmaceutical and Biological Chemistry, UCL School of Pharmacy, London, UK
}

\section{Edited by:}

Adejuwon Adewale Adeneye, Lagos

State University College of

Medicine, Nigeria

Reviewed by:

He-Hui Xie, Second Military Medical

University, China

Rong-Rong He, Jinan University,

China

\section{*Correspondence:}

Jose M. Prieto, Department of Pharmaceutical and Biological Chemistry, UCL School of Pharmacy, 29-39 Brunswick Square, London WC1N 1AX, UK e-mail: j.prieto@ucl.ac.uk
A plethora of active compounds found in herbal medicines can serve as substrate for enzymes involved in the metabolism of xenobiotics. When a medicinal plant is co-administered with a conventional drug and little or no information is known about the pharmacokinetics of the plant metabolites, there is an increased risk of potential herb-drug interactions. Moreover, genetic polymorphisms in a population may act to predispose individuals to adverse reactions. The use of herbal medicines is rapidly increasing in many countries, particularly Brazil where the vast biodiversity is a potential source of new and more affordable treatments for numerous conditions. Accordingly, the Brazilian Unified Public Health System (SUS) produced a list of 71 plant species of interest, which could be made available to the population in the near future. Physicians at SUS prescribe a number of essential drugs and should herbal medicines be added to this system the chance of herb-drug interactions further increases. A review of the effects of these medicinal plants on Phase 1 and Phase 2 metabolic mechanisms and the transporter P-glycoprotein was conducted. The results have shown that approximately half of these medicinal plants lack any pharmacokinetic data. Moreover, most of the studies carried out are in vitro. Only a few reports on herb-drug interactions with essential drugs prescribed by SUS were found, suggesting that very little attention is being given to the safety of herbal medicines. Here we have taken this information to discuss the potential interactions between herbal medicines and essential drugs prescribed to Brazilian patients whilst taking into account the most common polymorphisms present in the Brazilian population. A number of theoretical interactions are pinpointed but more pharmacokinetic studies and pharmacovigilance data are needed to ascertain their clinical significance.

Keywords: herb-drug interactions, cytochrome P450, glutathione, glucuronidation, P-glycoprotein, polymorphism, Brazil, pharmacovigilance

\section{INTRODUCTION}

Consumption of herbal medicines has been increasing worldwide over the past few years. In developed countries, such as the United Kingdom, around 50\% of the population have used herbal medicines at least once in their life and, surprisingly, almost $100 \%$ of HIV patients in the country have admitted to using herbal medicines (Caminal Homar, 2005). In developing countries, the World Health Organization (WHO) estimates that $65-80 \%$ of the population relies on herbal medicines as a primary source of treatment (Rahman and Singhal, 2002). These statistics are in line with Brazil, where $66 \%$ of the population have no access to commercial medicines (Trojan-Rodrigues et al., 2012). Even when access is granted, popular use of herbal medicines is often due to poor medical and pharmaceutical assistance and the high cost of treatment with conventional drugs (Silveira et al., 2008). Brazilians are also becoming more interested in "safe" and "natural" treatments aimed to promote healthier living. A consequence of this increased use of phytotherapy has been a higher number of case reports on adverse reactions caused by uncontrolled consumption of herbal medicines (Silveira et al., 2008).
The Brazilian Health Surveillance Agency (ANVISA) is in charge of the regulation of herbal medicines in the country and since its creation in 1999, many advances have been made in order to control and ensure their efficacy and safety (Balbino and Dias, 2010). To guarantee that the phytomedicinal candidate is safe for consumption by humans, the Agency established a requirement that at least 20 years of prior traditional use must be attested. In the absence of this evidence the efficacy and safety of the candidate needs to be demonstrated by a point based system according to literature data, preclinical and clinical tests or indication that the herb is already included in the List of Simplified Registration of Herbal Medicines (ANVISA, 2010). Although these regulations are relevant to improve the safety and efficacy of herbal medicines, pharmacokinetic studies on the plants are not yet a regulatory requirement. As a consequence, there is a scarcity of this kind of data which is regarded as an oversight in terms of safety (Ribeiro et al., 2005).

The SUS is one of the biggest public health systems in the world, responsible for approximately 140 million Brazilian citizens (Mendes, 2013). In order to establish which medicines 
should be provided by SUS, the Brazilian Health Ministry produced a list of essential drugs according to the International Classification of Diseases (ICD) and epidemiological studies conducted nationwide (Saúde, 2010; SUS, 2010). Several herbal medicines are already part of this list, such as Cynara scolymus L., Schinus terebinthifolius, and Rhamnus purshiana. However, due to the extensive number of plant species possessing pharmacological activity used in Brazil, the Health Ministry determined that more herbal medicines should be provided by the System to the population, as part of one of the aims of the National Policy of Integrative and Complementary Practices (PNPIC). Consequently, the list of medicinal plants of interest of SUS (RENISUS) was published in 2008 and, from this point on, efforts have been concentrated on elucidating the efficacy and safety of the 71 plant species present on the list (Saúde, 2009; SUS, 2009; cf. Feijó et al., 2012).

The pharmacokinetic profile of pharmaceutical drugs is essential to determine whether or not they will interact with other therapeutic interventions (Ionescu and Caira, 2005). Polymorphism studies are also relevant because they may impact the capacity to metabolize xenobiotics, thus leading to adverse drug reactions (ADRs) within certain ethnicities (Suarez-Kurtz, 2005). However, pharmacokinetic studies on medicinal plants are very difficult to carry out because of their chemical complexity (Simões and Mariot, 2003). As a result, there is very little data for numerous native and exotic plants that are traditionally used in Brazil (He et al., 2010). The in vitro pharmacokinetic profile of a few herbal medicines can be found in the literature and, although these data are important, they are seldom used for the prediction of potential herb-drug interactions. Thus, the aim of this article is to provide an overview and critical evaluation of the pharmacokinetic data of medicinal plants to be used in the Brazilian health system. By discussing the potential herb-drug interactions with essential drugs upon Phase 1 and Phase 2 metabolic mechanisms and P-Glycoprotein activity, we intend to prompt race awareness on the safety of herbal medicines in Brazil.

\section{METHODOLOGY}

A literature search was conducted using the Library of Medicine's PubMed database between May and June 2013. Included studies consisted of the reported effects of the medicinal plants of RENISUS list on the main liver metabolic enzymes, which are involved in Phase 1 (functionalization reactions mediated by cytochrome P450) and Phase 2 (glutathione conjugation, glucuronidation, sulfation, methylation and acetylation) metabolism and also the assessment of their effects on P-glycoprotein activity. The following combinations of keywords were used: "Plant name AND, 1A2, 3A4, 3A5, 3A7, 2C9, 2C19, 2D6, 2E1," "Plant name AND glutathione," or "Plant name AND gsh," "Plant name AND glucuronidation" or "Plant name AND ugt," "Plant name AND sulfation," "Plant name AND sulfate conjugation," "Plant name AND sulfotransferase," "Plant name AND methylation," "Plant name AND methyltransferase," "Plant name AND acetylation," "Plant name AND n-acetyltransferase," "Plant name AND P-glycoprotein" or "Plant name AND Pgp." EndNote web was the citation tool used to manage and organize all the references collected.
It is important to note that the list of Brazilian medicinal plants of interest of SUS encompass native and exotic adapted plant species and that we are aware of the chemical variability of the materials, which eventually may be harmonized by pharmacopoeial monographs of their respective countries.

\section{PHASE 1 METABOLISM AND THE HUMAN LIVER CYTOCHROMES P450}

Xenobiotic metabolism is normally divided into two phases: Phase 1 (functionalization reactions) and Phase 2 (conjugative reactions). Phase 1 reactions prepare the drug for Phase 2 metabolism by adding polar functional groups to the xenobiotic (Ionescu and Caira, 2005).

Human drug-metabolizing enzymes are present ubiquitously in the body. Over 50 human cytochromes $\mathrm{P} 450$ have already been isolated; the major ones found in the liver include CYP1A2, CYP2E1, CYP2C9/19, CYP2D6, and CYP3A4/5/7 (Figure 1) (Gibson and Skett, 2001). The CYP 1, 2, and 3 are the most abundant families of CYP metabolizing enzymes and the CYP1A2, CYP2C, and CYP3A4 isoforms account for about 30\% of the metabolism of the majority of drugs (Atkinson, 2012).

The cytochrome P450 monooxygenase enzymes are located in the smooth endoplasmic reticulum of the liver and other extra hepatic tissues. Numerous drugs are metabolized by cytochrome P450 enzymes through oxidation reactions such as aromatic and aliphatic hydroxylation, epoxidation, $\mathrm{N}$-dealkylation, $\mathrm{O}$ dealkilation, $S$-dealkylation, oxidative deamination, $N$-oxidation, $S$-oxidation, phosphothionate oxidation, dehalogenation, and alcohol oxidation. Reduction, hydrolysis and hydration are other examples of Phase 1 reactions catalyzed by the cytochrome P450 (Ionescu and Caira, 2005).

Similar to conventional drugs, herbal medicines also undergo Phase 1 and Phase 2 metabolism in order to be excreted from the body. If a herbal medicine is concomitantly used with a conventional drug, for example, the first may inhibit or induce the activity and expression of a specific cytochrome that could be the same one responsible for the metabolism of the latter, leading to herb-drug interactions (Hu et al., 2005).






\section{GENETIC POLYMORPHISM}

Responses to drug consumption differ among individuals due to the variability of CYP content. A predefined dosage of a medicine might be enough to exert a pharmacological effect in one patient but it may be necessary to be adjusted for another patient to achieve the same effect. This can be explained by genetic polymorphisms within CYPs that can affect the metabolism of xenobiotics in general, leading to changes in drug response and increased risk of ADRs (Zhou et al., 2009). For example, the biodisponibility of Omeprazole, which is a drug that is metabolized by CYP3A4 and CYP 2C19, demonstrated to be slower in Mexicans when compared with Caucasians but faster than that of Asians. The ethnic mixture of the Mexican population is a plausible explanation for differences in metabolic response compared to other ethnic groups (Gonzalez et al., 2003).

The genomic diversity of the Brazilian population is a result of the genetic admixture of three groups: Europeans, Africans and Amerindians. Due to this very distinctive miscegenation, polymorphisms in cytochromes levels are undoubtedly present among Brazilians (Suarez-Kurtz, 2005). The Brazilian National Pharmacogenetics/Pharmacogenomics Network (REFARGEN) carried out studies in four regions of Brazil in order to map the genetic diversity of the population (Suarez-Kurtz, 2004). The study divided the population into three distinct races: white, brown and black. The results obtained from REFARGEN showed that numerous polymorphisms were found on cytochromes $2 \mathrm{C} 9$, 2C19, 2D6, and 3A5.

Taking all these points into consideration, from the data gathered in our literature review we will summarize some potentially clinically relevant pharmacokinetic effects of herbal medicines in metabolic enzymes responsible for Phase 1 and Phase 2 metabolisms and P-glycoprotein activity. Also, the presence of polymorphisms among the Brazilian population and its implication in the metabolism were assessed. Some interactions between essential drugs and herbal medicines in Brazil found in the literature will be shown, which will eventually need to be put to test in the laboratory or followed up epidemiologically.

\section{EFFECTS OF HERBAL MEDICINES IN PHASE 1 ENZYMES AND HERB-DRUG INTERACTIONS \\ CYP1A2}

This cytochrome isoform is mainly found in the liver (15\%) and it metabolizes almost $20 \%$ of the current therapeutic arsenal (Wang and Zhou, 2009). Amid the 71 plant species, nine of them were found to interfere with the activity of CYP1A2 (Table 1). Examples of essential drugs, which are substrates for the CYP1A2, include the highly popular painkiller Acetaminophen, the betablocker Propranolol, the antidepressant Clomipramine and the anticoagulant Warfarin.

Acetaminophen (Paracetamol) is bioactivated via CYP1A2, CYP3A4, and CYP2E1, resulting in the production of the toxic compound $\mathrm{N}$-acetyl-p-benzoquinone (NAPQI). In normal conditions, the drug is detoxified by conjugation with glutathione. However, in cases of overdose, this metabolic route becomes saturated, increasing the bioactivation of NAPQI and its binding to other molecules, such as proteins, resulting in damages to the liver due to cell death (Lee et al., 2001). Intake of Acetaminophen
Table 1 | Medicinal plant species listed in RENISUS with reported effects of on CYP1A2.

\begin{tabular}{|c|c|c|}
\hline $\begin{array}{l}\text { Plant } \\
\text { species/Family }\end{array}$ & Effects on CYP1A2 & References \\
\hline $\begin{array}{l}\text { Allium sativum } \\
\text { (Aliaceae) }\end{array}$ & + & Le Bon et al., 2003 \\
\hline $\begin{array}{l}\text { Curcuma longa } \\
\text { (Zingiberaceae) }\end{array}$ & + & Thapliyal et al., 2002 \\
\hline $\begin{array}{l}\text { Eucalyptus } \\
\text { globulus } \\
\text { (Myrtaceae) }\end{array}$ & - & $\begin{array}{l}\text { Unger and Frank, } \\
2004\end{array}$ \\
\hline $\begin{array}{l}\text { Glycine max } \\
\text { (Leguminosae) }\end{array}$ & - & Shon and Nam, 2004 \\
\hline $\begin{array}{l}\text { Harpagophytum } \\
\text { procumbens } \\
\text { (Pedaliaceae) }\end{array}$ & $\mathrm{NE},-$ & $\begin{array}{l}\text { Unger and Frank, } \\
\text { 2004; Modarai et al., } \\
2011\end{array}$ \\
\hline $\begin{array}{l}\text { Mentha piperita } \\
\text { (Lamiaceae) }\end{array}$ & - & $\begin{array}{l}\text { Unger and Frank, } \\
2004\end{array}$ \\
\hline $\begin{array}{l}\text { Phyllanthus } \\
\text { amarus } \\
\text { (Euphorciaceae) }\end{array}$ & - & $\begin{array}{l}\text { Hari Kumar and } \\
\text { Kuttan, } 2006\end{array}$ \\
\hline $\begin{array}{l}\text { Punica granatum } \\
\text { (Lythraceae) }\end{array}$ & - & Faria et al., 2007a \\
\hline $\begin{array}{l}\text { Trifolium } \\
\text { pratense } \\
\text { (Fabaceae) }\end{array}$ & - & $\begin{array}{l}\text { Unger and Frank, } \\
2004\end{array}$ \\
\hline
\end{tabular}

+, Enzyme induction; -, Enzyme inhibition; NE, No Effect.

with Allium sativum and Curcuma longa could theoretically increase the toxicity of the drug due to accumulation of NAPQI caused by induction of CYP1A2. On the other hand, consumption of Acetaminophen with medicinal plants such as Phyllantus amarus, Mormodica charantia, Eucalyptus globulus, Glycine max, Harpagophytum procumbens, Mentha piperita, Trifolium pratense and Punica granatum based remedies may decrease levels of this toxic metabolite because of CYP1A2 enzyme inhibition.

Although it appears that garlic consumption can put the integrity of hepatocytes at risk, a study conducted by Gwilt et al. (1994) proved that the garlic extract administration has little effect on the metabolism of Acetaminophen. In this study 16 male nonsmokers took $10 \mathrm{ml}$ of garlic extract daily for 3 months. Acetaminophen was administered at five different time points: before garlic treatment, at the end of the first, second, and third month of garlic extract consumption and 1 month after interruption of garlic treatment. The results demonstrated that garlic extract does not interfere with the oxidative pathway of Acetaminophen and therefore it does not represent a potential risk for hepatocytes.

The beta-blocker Propranolol and the tricyclic antidepressant Clomipramine are essential drugs extensively prescribed in Brazil. The biotransformation of Propranolol and Clomipramine starts with the $N$-dealkilation, governed by $S$-mephenytoin (CYP1A2) for the former and the $N$-demethylation of the side chain of the molecule of the latter to form the active metabolite desmethylclomipramine (DCIP) (Nielsen et al., 1996). Therefore, plant species that inhibit CYP1A2 must be avoided during the 
treatment period with these drugs. This is, however, theoretical and in this case no reports have so far been found in the literature.

The anticoagulant Warfarin is indicated for the treatment of venous thrombosis and pulmonary embolism. The pharmacokinetics of this drug can easily be altered by CYP1A2 inhibitors. A rare case of interaction of warfarin with garlic supplements has been reported, leading to excessive bleeding (Baxter and Stockley, 2008). Other cases of herb-drug interactions were detected after co-administration of Curcuma longa, Glycine max, Harpagophytum procumbens, Punica granatum, and Trifolium pratense with Warfarin, resulting in pharmacokinetic alterations (Heck et al., 2000; Cambria-Kiely, 2002; Ramsay et al., 2005; Komperda, 2009; Liu et al., 2013).

CYP1A2 is considered to be highly inducible and polymorphic. Two polymorphisms were found to be common in South Brazilians: the CYP1A2* $1 \mathrm{~F}$ and ${ }^{*} 1 \mathrm{~K}$ alleles. They cause higher and decreased enzyme expression, respectively (Kohlrausch et al., 2014). Their high frequency in Southern Brazilians suggests that chances of ADRs may be increased within this group.

\section{CYP2C9}

The CYP2C9 is the major CYP2C isoform found in the human liver and typical substrates are molecules that contain an anionic site and a hydrophobic site (Mo et al., 2009). This CYP enzyme metabolizes approximately $15 \%$ of clinical drugs, including the nonsteroidal anti-inflammatory (NSAID) Ibuprofen, the antihypertensive Losartan, the antidepressant Fluoxetine, the antiepileptic Phenytoin and the anti-hypercholesterolemic Fluvastatin (Baxter and Stockley, 2008; Berka et al., 2011). Certain endogenous bioactive substances such as steroids, melatonin, retinoids and arachidonic acid are also metabolized by this CYP family (Mo et al., 2009).

Ibuprofen is a common medication prescribed by SUS to combat pain and inflammation. The drug is also included in the WHO Model List of Essential Medicines as a drug for pain and palliative care and as an antimigraine medicine (Medicines, 2012; WHO, 2012, 2013). As mentioned above, Ibuprofen is mostly metabolized by CYP2C9 leading to the formation of the active metabolite $(S)$-ibuprofen. Herbal species that are substrates for CYP2C9 (Table 2), may inhibit the formation of $(S)$-ibuprofen, potentially leading to therapeutic failure (Mo et al., 2009).

The active metabolites E-3174, norfluoetine, $4^{\prime}-\mathrm{HPPH}$ and 6hydroxy fluvastatin, are formed through the action of CYP2C9 on the essential drugs Losartan, Fluoxetine, Phenytoin and Fluvastatine, respectively (von Moltke et al., 1997; Scripture and Pieper, 2001; Joy et al., 2009). Concomitant consumption of those drugs along with any of the plant species listed on Table 2 could impact on the formation of these substances.

The CYP2C9*2 and * 11 alleles were found in higher frequency in white Brazilians, whereas CYP2C $9 * 3$ was mostly found in browns and CYP2C9* 5 in the black population. These polymorphisms decrease the enzyme activity in vitro (Zhou et al., 2009) therefore consumption of medicinal plants such as garlic, eucalyptus, devil's claw, mentha, pomegranate, red clover and ginger may further inhibit their function or expression, potentially causing herb-drug interactions in these ethnic groups.
Table 2 | Medicinal plant species listed in RENISUS with reported effects of on CYP2C9.

\begin{tabular}{|c|c|c|}
\hline $\begin{array}{l}\text { Plant } \\
\text { species/Family }\end{array}$ & Effects on CYP2C9 & References \\
\hline $\begin{array}{l}\text { Allium sativum } \\
\text { (Aliaceae) }\end{array}$ &,-+ & $\begin{array}{l}\text { Foster et al., 2001; } \\
\text { Ho et al., } 2010\end{array}$ \\
\hline $\begin{array}{l}\text { Eucalyptus globulus } \\
\text { (Myrtaceae) }\end{array}$ & - & $\begin{array}{l}\text { Unger and Frank, } \\
2004\end{array}$ \\
\hline $\begin{array}{l}\text { Harpagophytum } \\
\text { procumbens } \\
\text { (Pedaliaceae) }\end{array}$ & $\mathrm{NE},-$ & Modarai et al., 2011 \\
\hline $\begin{array}{l}\text { Mentha piperita } \\
\text { (Lamiaceae) }\end{array}$ & - & $\begin{array}{l}\text { Unger and Frank, } \\
2004\end{array}$ \\
\hline $\begin{array}{l}\text { Punica granatum } \\
\text { (Lythraceae) }\end{array}$ & - & Hanley et al., 2012 \\
\hline $\begin{array}{l}\text { Trifolium pratense } \\
\text { (Fabaceae) }\end{array}$ & - & $\begin{array}{l}\text { Unger and Frank, } \\
2004\end{array}$ \\
\hline $\begin{array}{l}\text { Zingiber officinale } \\
\text { (Zingiberaceae) }\end{array}$ & - & Kimura et al., 2010 \\
\hline
\end{tabular}

+, Enzyme induction; -, Enzyme inhibition; NE, No Effect.

\section{CYP2C19}

Cytochrome P450 2C19 is not only involved in the metabolism of a range of drugs but it also plays a crucial role in the detoxification and inactivation of some potential carcinogens (Wang et al., 2013). CYP2C19 is responsible for the metabolism of about $10 \%$ of prescribed drugs, including a number of essential ones such as the proton pump inhibitor Omeprazole, the tricyclic antidepressant Amitriptyline, the selective serotonin reuptake inhibitor Fluoxetine, the benzodiazepine Diazepam and the barbiturate Phenobarbital (Zhou et al., 2009). About 24 variants of CYP2C19 are known of which three of them were found by REFARGEN in the Brazilian population: CYP2C19*2, CYP2C19*3, and CYP2C19*17. The alleles *2 and *3 appear not to effect the enzyme activity, whereas CYP2C19*17 increases in vitro activity and is the most prevalent.

The plant species Allium sativum, Eucalyptus globulus, Mentha piperita, and Trifolium pratense were found to be CYP2C19 inhibitors (Table 3). Due to the extensive use of these herbal medicines that are metabolized by CYP2C19, herb-drug interactions at this level could be very frequent but so far no clinical report has been found.

\section{CYP2D6}

Although the level of expression of the cytochrome P450 2D6 in the human liver is only about $5 \%$, it metabolizes about $25 \%$ of all medications in human liver (Ionescu and Caira, 2005). Essential drugs such as the beta-blockers Propafenone and Timolol, the antidepressant Amitriptyline, the antipsychotic Haloperidol and Risperidone, and the antihistamine Chlorphenamine are metabolized by this isoform (Zhou et al., 2009). Polymorphisms on CYP2D6 are the most studied among the CYPs. To date, 72 variants of this isoform were found in humans and 16 were detected in Brazilians according to REGARGEN: CYP2D6*1, *2, *3, *4, *5, ${ }^{*} 9, * 10, * 17, * 29, * 34, * 35, * 39, * 41,{ }^{*} 1 \mathrm{XN},{ }^{*} 2 \mathrm{XN}$, and ${ }^{*} 4 \mathrm{XN}$. An increase in enzyme activity was found on the alleles $* 1 \mathrm{XN}$ and 
Table 3 | Medicinal plant species listed in RENISUS with reported effects of on CYP2C19.

\begin{tabular}{lcl}
\hline $\begin{array}{l}\text { Plant } \\
\text { species/Family }\end{array}$ & Effects on CYP2C19 & References \\
\hline $\begin{array}{l}\text { Allium sativum } \\
\text { (Aliaceae) }\end{array}$ & - & Foster et al., 2001 \\
$\begin{array}{l}\text { Eucalyptus globulus } \\
\text { (Myrtaceae) }\end{array}$ & - & \\
$\begin{array}{l}\text { Harpagophytum } \\
\text { procumbens }\end{array}$ & & Unger and Frank, \\
(Pedaliaceae) & NE & Modarai et al., 2011 \\
$\begin{array}{l}\text { Mentha piperita } \\
\text { (Lamiaceae) }\end{array}$ & & \\
Trifolium pratense & - & Unger and Frank, \\
(Fabaceae) & - & 2004 \\
\hline
\end{tabular}

+, Enzyme induction; -, Enzyme inhibition; NE, No Effect.

${ }^{*} 2 \mathrm{XN}$, whereas a decrease of activity was found on $* 9,{ }^{*} 10,{ }^{*} 17$, $* 29$, and $* 41$.

The popular medicinal plants Eucalyptus globulus, Harpagophytum procumbens, Mentha piperita, Phylanthus amarus, Punica granatum, and Trifolium pratense are shown to inhibit the activity of CYP2D6 in liver cells (Table 4). Brazilians who take these herbal drugs may have increased chances of ADRs, although no clinical reports were found in the literature.

\section{CYP2E1}

The cytochrome P450 2E1 represents $10 \%$ of the total CYPs expressed in the human liver and it is well known for its involvement in the metabolism of ethanol to acetaldehyde, and accordingly it is rapidly induced after ethanol ingestion (Anzenbacher and Anzenbacherova, 2001). This cytochrome isoform is responsible for the activation of some carcinogens, procarcinogens and toxicants and it metabolizes mainly low-molecular-weight compounds. CYP2E1 also has the ability to produce reactive intermediates, leading to the formation of free radicals such as superoxide, hydroxyl radical, and lipid peroxides (Neafsey et al., 2009). Polymorphisms on CYP2E1 in the Brazilian population have not yet been mapped by REFARGEN, but one case of herbdrug interaction involving this enzyme has been reported (Hau et al., 2009). According to our literature search, Allium sativum, Momordica chrantia, Phyllanthus amarus, Phyllanthus urinaria, and Punica granatum decrease levels and activity of CYP2E1 in the liver (Table 5). As Acetaminophen is also metabolized by CYP2E1, NAPQI can be also formed at this metabolic route. Therefore, consumption of these medicinal plants could reduce the formation of the toxic metabolite. For example, species of the Phyllanthus genus are traditionally used for conditions such as jaundice, gonorrhea, frequent menstruation, diabetes and as a pain killer (Naaz et al., 2007; Patel et al., 2011). A study revealed that Phyllanthus urinaria inhibits CYP2E1 activity in hepatocytes and it also attenuates acetaminophen induced hepatotoxicity in mice. The experiment was conducted by treating a total of 37 mice with acetaminophen at a dose of $550 \mathrm{mg} / \mathrm{kg}$ of body weight on day one in order to induce liver injury. The mice were then divided into two groups: the first group was treated with Phyllanthus
Table 4 | Medicinal plant species listed in RENISUS with reported effects of on CYP2D6.

\begin{tabular}{lcl}
\hline $\begin{array}{l}\text { Plant } \\
\text { species/Family }\end{array}$ & Effects on CYP2D6 & References \\
\hline $\begin{array}{l}\text { Allium sativum } \\
\text { (Aliaceae) }\end{array}$ & NE & Markowitz et al., \\
$\begin{array}{l}\text { Eucalyptus globulus } \\
\text { (Myrtaceae) }\end{array}$ & - & 2003 \\
Harpagophytum & & Unger and Frank, \\
procumbens & NE, - & Modarai et al., 2011 \\
(Pedaliaceae) & & \\
$\begin{array}{l}\text { Mentha piperita } \\
\text { (Lamiaceae) }\end{array}$ & & \\
$\begin{array}{l}\text { Phyllanthus amarus } \\
\text { (Euphorbiaceae) }\end{array}$ & - & Unger and Frank, \\
$\begin{array}{l}\text { Punica granatum } \\
\text { (Lythraceae) }\end{array}$ & - & Hari Kumar and \\
Trifolium pratense & & Kuttan, 2006 \\
(Fabaceae) & - & Usia et al., 2006 \\
\hline
\end{tabular}

+, Enzyme induction; -, Enzyme inhibition; NE, No Effect.

Table 5 | Medicinal plant species listed in RENISUS with reported effects of on CYP2E1.

Plant $\quad$ Effects on CYP2E1 References
species/Family

\begin{tabular}{|c|c|c|}
\hline $\begin{array}{l}\text { Allium sativum } \\
\text { (Aliaceae) }\end{array}$ & - & Le Bon et al., 2003 \\
\hline $\begin{array}{l}\text { Curcuma longa } \\
\text { (Zingiberaceae) }\end{array}$ & $\mathrm{NE}$ & Salama et al., 2013 \\
\hline $\begin{array}{l}\text { Glycine max } \\
\text { (Leguminosae) }\end{array}$ & $\mathrm{NE}$ & $\begin{array}{l}\text { Shon and Nam, } \\
2004\end{array}$ \\
\hline $\begin{array}{l}\text { Momordica charantia } \\
\text { (Cucurbitaceae) }\end{array}$ & & Raza et al., 1996 \\
\hline $\begin{array}{l}\text { Phyllanthus amarus } \\
\text { (Euphorbiaceae) }\end{array}$ & & $\begin{array}{l}\text { Hari Kumar and } \\
\text { Kuttan, } 2006\end{array}$ \\
\hline $\begin{array}{l}\text { Phyllanthus urinaria } \\
\text { (Euphorbiaceae) }\end{array}$ & & Shen et al., 2008 \\
\hline $\begin{array}{l}\text { Punica granatum } \\
\text { (Lythraceae) }\end{array}$ & & Faria et al., 2007a \\
\hline
\end{tabular}

+, Enzyme induction; Enzyme inhibition; NE, No Effect.

urinaria extract from day 2 to 4 whereas the second group just received water. The final results indicated that the herbal drug was able to inhibit the formation of NAPQI and, consequently, prevent liver failure (Hau et al., 2009).

\section{CYP3A}

The most abundant subfamily of cytochromes is CYP3A (it represents about $30 \%$ of the entire CYP450 enzymes in the liver) and it is responsible for processing more than $50 \%$ of therapeutic drugs. CYP3A exists in the body in three isoforms: $3 \mathrm{~A} 4$, $3 \mathrm{~A} 5$, and $3 \mathrm{~A} 7$. CYP3A5 is more often detected in adolescents than in adults, where it is hardly inducible. CYP3A4 is mostly glucocorticoid-inducible and CYP3A7 (found only in fetal livers) has a role in hydroxylations of allylic and benzylic carbon 
atoms (Ionescu and Caira, 2005). According to our findings, practically all the medicinal plants that demonstrated activity in the Phase 1 metabolism are substrates for the CYP3A family (Table 6). Macrolide antibiotics, anti-arrythmics, benzodiazepines, immune modulators, HIV antivirals, antihistamines, calcium channel blockers and HMG CoA reductase inhibitors are examples of classes of medications metabolized by the CYP3A subfamily (Zhou et al., 2009). The probability of herb-drug interactions with this isoform is high and therefore a particular attention to all CYP3A substrates should be given in order to avoid herb-drug interactions.

HIV positive patients are commonly treated with the essential drug Saquinavir. At the same time, dietary supplements such as garlic and/or immune system boosters like Cat's claw can be used to help prevent, combat and improve health. In 1998, a case report was published demonstrating that Saquinavir is a substrate of CYP3A4 and that garlic (an inhibitor of CYP3A) was able to interfere with the metabolism of the drug, leading to failures in therapy and possible drug resistance (Chen et al., 2011). Another case report showed that a 45-year-old woman, who was HIV positive and had cirrhosis caused by a hepatitis $\mathrm{C}$ infection was not responding satisfactorily to the treatment of the anti-HIV drugs.

\begin{tabular}{|c|c|c|}
\hline $\begin{array}{l}\text { Plant } \\
\text { species/Family }\end{array}$ & Effects on CYP3A & References \\
\hline $\begin{array}{l}\text { Allium sativum } \\
\text { (Aliaceae) }\end{array}$ & $\mathrm{NE},-\left({ }^{*} / * * /^{* *}\right)$ & $\begin{array}{l}\text { Foster et al., 2001; } \\
\text { Hajda et al., } 2010\end{array}$ \\
\hline $\begin{array}{l}\text { Chamomilla recutita } \\
\text { (Asteraceae) }\end{array}$ & $-\left(^{*}\right)$ & $\begin{array}{l}\text { Budzinski et al., } \\
2000\end{array}$ \\
\hline $\begin{array}{l}\text { Curcuma longa } \\
\text { (Zingiberaceae) }\end{array}$ & $\mathrm{NE}\left({ }^{*}\right)$ & $\begin{array}{l}\text { Graber-Maier } \\
\text { et al., } 2010\end{array}$ \\
\hline $\begin{array}{l}\text { Eucalyptus globulus } \\
\text { (Myrtaceae) }\end{array}$ & $-\left({ }^{*}\right)$ & $\begin{array}{l}\text { Unger and Frank, } \\
2004\end{array}$ \\
\hline $\begin{array}{l}\text { Foeniculum vulgare } \\
\text { (Apiaceae) }\end{array}$ & $-\left(^{*}\right)$ & $\begin{array}{l}\text { Subehan et al., } \\
\text { 2006, } 2007\end{array}$ \\
\hline $\begin{array}{l}\text { Harpagophytum } \\
\text { procumbens } \\
\text { (Pedaliaceae) }\end{array}$ & $\mathrm{NE},-\left({ }^{*}\right)$ & $\begin{array}{l}\text { Unger and Frank, } \\
\text { 2004; Modarai } \\
\text { et al., } 2011\end{array}$ \\
\hline $\begin{array}{l}\text { Mentha piperita } \\
\text { (Lamiaceae) }\end{array}$ & $-\left({ }^{*}\right)$ & $\begin{array}{l}\text { Unger and Frank, } \\
2004\end{array}$ \\
\hline $\begin{array}{l}\text { Mormodica charantia } \\
\text { (Cucurbitaceae) }\end{array}$ & $-\left(^{*}\right)$ & Raza et al., 1996 \\
\hline $\begin{array}{l}\text { Phyllanthus amarus } \\
\text { (Euphorbiaceae) }\end{array}$ & $-\left(*{ }^{* *} /{ }^{* *}\right)$ & $\begin{array}{l}\text { Hari Kumar and } \\
\text { Kuttan, } 2006\end{array}$ \\
\hline $\begin{array}{l}\text { Punica granatum } \\
\text { (Lythraceae) }\end{array}$ & $-\left({ }^{*} /{ }^{* *} /{ }^{* *}\right)$ & Faria et al., 2007a \\
\hline $\begin{array}{l}\text { Trifolium pratense } \\
\text { (Fabaceae) }\end{array}$ & $-\left(^{*}\right)$ & $\begin{array}{l}\text { Budzinski et al., } \\
2000\end{array}$ \\
\hline $\begin{array}{l}\text { Uncaria tomentosa } \\
\text { (Rubiaceae) }\end{array}$ & $-\left(^{*}\right)$ & $\begin{array}{l}\text { Budzinski et al., } \\
2000\end{array}$ \\
\hline $\begin{array}{l}\text { Zingiber officinale } \\
\text { (Zingiberaceae) }\end{array}$ & $(*)$ & Kimura et al., 2010 \\
\hline
\end{tabular}

${ }^{*}$ CYP3A4, ${ }^{* *}$ CYP3A5, ${ }^{* *}$ CYP3A7/4, Enzyme induction; - , Enzyme inhibition; NE, No Effect.
The patient had no good adherence to the HIV treatment so was then asked whether she was making use of any other medicines, including herbal medicines. Surprisingly, the patient was taking Uncaria tomentosa preparation for 2 months, probably to enhance the immune system. She was asked to cease taking of the herbal medicine and after 15 days the $\mathrm{C}_{\min }$ values of the anti-HIV drugs were normalized. As shown in Table 6, Uncaria tomentosa has a high inhibitory capability to CYP3A4 causing an increase in the $\mathrm{C}_{\min }$ values for antiretroviral agents leading to an increased risk of toxicity. The combined therapy with these two agents has been shown to be a potential risk for HIV patients (Lopez Galera et al., 2008).

Another example of a CYP3A substrate is the HMG CoA reductase inhibitor Atorvastatin. This essential medicine is indicated for patients with dyslipidemia, reducing levels of total cholesterol, low-density lipoprotein cholesterol (LDL), triglycerides, very low-density lipoprotein cholesterol (VLDL) and for increasing high-density lipoprotein cholesterol (HDL) levels. A pharmacokinetic study conducted in 2012 showed that the halflife of the drug was increased in rats treated with Allium sativum due to inhibition of CYP3A4 by the herbal medicine (Reddy et al., 2012).

REFARGEN has reported CYP3A5 polymorphisms among Brazilians with the most frequent alleles being CYP3A $5^{*} 1,{ }^{*} 3$, $* 6$, and $* 7$. The alleles $* 3$ and $* 6$ decrease enzyme activity in vitro, whereas $* 1$ and $* 7$ showed no effects (Zhou et al., 2009). Interestingly, the allele $* 3$ is the most common variation of this isoform in Brazil. Because it reduces the enzyme activity, intake of herbal medicines that exert the same effect should be strongly avoided in order to prevent herb-drug interactions.

\section{PHASE 2 METABOLISM AND POTENTIAL PHARMACOKINETIC HERB-DRUG INTERACTIONS}

Phase 2 metabolism reactions (or Conjugation reactions) occur when metabolic enzymes react with functional groups of a drug that was formed during the Phase 1 process. Endogenous species, such as a sugar or an amino acid, are added to the drug in order to increase the polarity to allow its elimination. The two main Phase 2 biotransformation reactions are glutathione conjugation and glucuronidation but the other conjugative reactions such as sulfonation, methylation and acetylation are also relevant (Atkinson, 2012).

\section{GLUTATHIONE CONJUGATION (GSH)}

Glutathione is a tripeptide present in high concentrations in the liver. It has a protective role removing toxic electrophilic compounds from the body (Ionescu and Caira, 2005). Conjugation with glutathione avoids the reaction of electrophilic compounds to nucleophilic ones in macromolecules such as proteins and nucleic acids. When the conjugate is formed, it has to undergo further metabolic reactions in order to form mercapturic acid. The final product is then eliminated from the organism (Sies and Ketterer, 1988).

The plant species on Table 7 can affect the glutathione levels in liver cells according to our literature search. The metabolite NAPQI, generated by the CYP isoforms 2E1, 3A4, and 1A2, undergoes glutathione conjugation (Baxter and Stockley, 2008). 
Table 7 | Medicinal plant species listed in RENISUS with reported effects of on glutathione levels.

\begin{tabular}{|c|c|c|}
\hline Plant species/Family & $\begin{array}{c}\text { Effects on } \\
\text { glutathione levels }\end{array}$ & References \\
\hline $\begin{array}{l}\text { Achillea millefoilum } \\
\text { (Asteraceae) }\end{array}$ & + & Potrich et al., 2010 \\
\hline $\begin{array}{l}\text { Allium sativum } \\
\text { (Aliaceae) }\end{array}$ & + & Ip and Lisk, 1997 \\
\hline $\begin{array}{l}\text { Aloe vera/Aloe } \\
\text { barbadensis (Aloaceae) }\end{array}$ &,-+ & $\begin{array}{l}\text { Kaithwas et al., } \\
\text { 2011; Hegazy et al., } \\
2012\end{array}$ \\
\hline $\begin{array}{l}\text { Anacardium } \\
\text { occidentale } \\
\text { (Anacardiaceae) }\end{array}$ & + & Singh et al., 2004 \\
\hline $\begin{array}{l}\text { Baccharis trimera } \\
\text { (Asteraceae) }\end{array}$ & - & Nogueira et al., 2011 \\
\hline $\begin{array}{l}\text { Bauhinia forficata } \\
\text { (Caesalpiniaceae) }\end{array}$ & - & $\begin{array}{l}\text { Damasceno et al., } \\
2004\end{array}$ \\
\hline $\begin{array}{l}\text { Bauhinia variegata } \\
\text { (Caesalpiniaceae) }\end{array}$ & + & $\begin{array}{l}\text { Rajkapoor et al., } \\
2006\end{array}$ \\
\hline $\begin{array}{l}\text { Calendula officinalis } \\
\text { (Asteraceae) }\end{array}$ & + & $\begin{array}{l}\text { Preethi and Kuttan, } \\
2009\end{array}$ \\
\hline $\begin{array}{l}\text { Chamomilla recutita } \\
\text { (Asteraceae) }\end{array}$ & + & Al-Hashem, 2010 \\
\hline $\begin{array}{l}\text { Croton cajucara } \\
\text { (Euphorbiaceae) }\end{array}$ & + & Rabelo et al., 2010 \\
\hline $\begin{array}{l}\text { Curcuma longa } \\
\text { (Zingiberaceae) }\end{array}$ & + & Rong et al., 2012 \\
\hline $\begin{array}{l}\text { Cynara scolymus } \\
\text { (Asteraceae) }\end{array}$ &,$+ N E$ & $\begin{array}{l}\text { Miccadei et al., } \\
2008\end{array}$ \\
\hline $\begin{array}{l}\text { Foeniculum vulgare } \\
\text { (Apiaceae) }\end{array}$ & + & Zhang et al., 2012 \\
\hline $\begin{array}{l}\text { Glycine max } \\
\text { (Leguminosae) }\end{array}$ & + & Barbosa et al., 2011 \\
\hline $\begin{array}{l}\text { Mentha pulegium } \\
\text { (Lamiaceae) }\end{array}$ & + & Alpsoy et al., 2011 \\
\hline $\begin{array}{l}\text { Mentha piperita } \\
\text { (Lamiaceae) }\end{array}$ & + & Sharma et al., 2007 \\
\hline $\begin{array}{l}\text { Mikania glomerata } \\
\text { (Asteraceae) }\end{array}$ & $\mathrm{NE}$ & Barbosa et al., 2012 \\
\hline $\begin{array}{l}\text { Momordica charantia } \\
\text { (Cucurbitaceae) }\end{array}$ & + & $\begin{array}{l}\text { Raza et al., 2000, } \\
1996\end{array}$ \\
\hline $\begin{array}{l}\text { Phyllanthus amarus } \\
\text { (Euphorbiaceae) }\end{array}$ & + & $\begin{array}{l}\text { Kumar and Kuttan, } \\
\text { 2004, 2005; Karuna } \\
\text { et al., 2009; Maity } \\
\text { et al., } 2013\end{array}$ \\
\hline $\begin{array}{l}\text { Phyllanthus niruri } \\
\text { (Euphorbiaceae) }\end{array}$ & + & $\begin{array}{l}\text { Bhattacharjee and } \\
\text { Sil, 2006; Manjrekar } \\
\text { et al., } 2008\end{array}$ \\
\hline $\begin{array}{l}\text { Psidium guajava } \\
\text { (Myrtaceae) }\end{array}$ & + & Tandon et al., 2012 \\
\hline $\begin{array}{l}\text { Punica granatum } \\
\text { (Myrtaceae) }\end{array}$ &,+- & $\begin{array}{l}\text { Faria et al., 2007b; } \\
\text { Dassprakash et al., } \\
2012\end{array}$ \\
\hline $\begin{array}{l}\text { Ruta graveolens } \\
\text { (Rutaceae) }\end{array}$ & + & $\begin{array}{l}\text { Ratheesh et al., } \\
2011\end{array}$ \\
\hline $\begin{array}{l}\text { Zingiber officinale } \\
\text { (Zingiberaceae) }\end{array}$ &,$+ N E$ & Ajith et al., 2007 \\
\hline
\end{tabular}

+, Enzyme induction; - Enzyme inhibition; NE, No Effect.
When production of NAPQI exceeds liver stores of glutathione, the organ is damaged due to the attachment of NAPQI to liver proteins (Alipour et al., 2013). Thus, a combined therapy of acetaminophen and herbal species that deplete glutathione levels, listed in Table 7, should be monitored.

A study demonstrated that consumption of garlic extract protects hepatocytes against acetaminophen-induced glutathione depletion. In order to measure glutathione levels, hepatocytes were isolated from male Sprague-Dawley rats and incubated with different concentrations of garlic extract at three different times: before, at the same time and $30 \mathrm{~min}$ after addition of acetaminophen. The results were collected at different time points (from 0 to $150 \mathrm{~min}$ ) and it was observed that the intake of garlic extract is able to protect hepatocytes against acetaminopheninduced toxicity by increasing intracellular GSH levels (Anoush et al., 2009).

Studies on polymorphisms in the Brazilian population of enzymes in glutathione conjugation, such as glutathione $S$-tranferase (GST) have not been carried out by REFARGEN. However, some reports revealed its existence among this population. A study conducted by Rossini et al. (2002) reported the existence of GST polymorphisms in a group of 519 Brazilians from Rio de Janeiro. GSTM1 is involved in the detoxification of polycyclic aromatic hydrocarbons and some mutagens, whereas GSTT1 catalyzes the metabolism of halomethanes by human erythrocytes. It was found that the null allele, i.e., no expression of the enzyme, was detected in approximately $10 \%$ of the studied population. Null individuals are generally more susceptible to DNA damage by the action of the compounds already mentioned. Although we cannot extrapolate this data for all Brazilians, the existence of these polymorphisms is thought to be quite common among multi-ethnic populations. Therefore, the extensive list of plant species found to affect the glutathione conjugation mechanism plus the presence of such polymorphisms could potentially increase chances of herb-drug interactions.

\section{GLUCURONIDATION}

Glucuronidation is a mechanism in which a glucuronide is formed by the reaction between the electrophilic C-1 atom of the pyranose acid ring of the co-factor UDPGA (uridine 5'-diphosphate-glucuronic acid) with the substrate catalyzed by UDP-glucuronosyltransferases (UGTs). Uridine diphosphate glucuronosyltransferases (UGT's) are the most important Phase 2 enzymes and they are found in the highest amount among all conjugation enzymes in the liver (Ionescu and Caira, 2005; Caira and Ionescu, 2006). This is the most important form of conjugation of xenobiotics with chemical groups such as alcohols, phenols, hydroxylamines, carboxylic acids, amines, sulphonamides, and thiols (Gibson and Skett, 2001).

Phase 1 metabolites of nonsteroidal anti-inflammatory drugs (NSAIDs), such as Ibuprofen, predominantly undergo glucuronidation in order to be eliminated from the organism (Kuehl et al., 2005). Allium sativum increases the expression of UGTs whereas Curcuma longa inhibits the expression of these enzymes in the liver (Table 8). Therefore, the pharmacokinetic of this class of drugs can be compromised by consumption of any of these herbal species. 
REFARGEN has not yet published data about polymorphisms on UDP- glucuronosyltransferase enzymes. However, information about polymorphic UGTs and its impact on ADRss and cancer susceptibility have been reported (Guillemette, 2003).

\section{OTHER CONJUGATIVE REACTIONS}

Besides the two main liver conjugation reactions (glutathione conjugation and glucuronidation), the xenobiotic transformation could also happen by sulfation (or sulfate conjugation), methylation (or methyl conjugation), and acetylation (Ionescu and Caira, 2005).

Sulfation is another Phase 2 detoxification mechanism that is recognized to be the major conjugation pathway for phenols, alcohols, amines and thiols (Ionescu and Caira, 2005). Before the Phase 1 metabolites undergo sulfate conjugation, the inorganic sulfate has to be activated via ATP to form adenosine- $5^{\prime}$-phosphosulphate (APS) and, consequently, $3^{\prime}$ phosphoadenosine- $5^{\prime}$-phosphosulphate (PAPS). Sulfotransferase enzymes (SULT) will then catalyze the detoxification of essential drugs, such as Salbutamol and Acetaminophen by transferring a sulfuryl group from PAPS to an acceptor molecule (Gibson and Skett, 2001). Methylation is the mainly metabolic pathway for endogenous compounds but it could be also the route of many drugs and xenobiotics in general (Weinshilboum, 1988). Methyl conjugate reactions are only possible in the presence of the co-factor $S$-adenosylmethionine (SAM) and will result in the formation of $\mathrm{O}$-methylated, $\mathrm{N}$ methylated, and $S$-methylated products (Gibson and Skett, 2001). The liver is the primary site for acetylation reactions, but the reaction could also happen in some extra hepatic sites, such as the spleen, lungs and gut. To summarize, the $\mathrm{N}$-acetyltransferases will catalize the transferring of the cofactor acetyl-coenzyme A (acetyl-CoA) to aromatic amines and sulphonamides and form the polar metabolites (Ionescu and Caira, 2005).

After the literature search, it was concluded that the 71 plant species that are the focus of this review need to have their pharmacokinetic profile studied, because no such data has been published. The risk of potential herb-drug interactions caused by herbal medicines that are metabolized through sulfation, methylation and acetylation pathways is therefore increased and it could be already affecting the efficacy of conventional drugs. REFARGEN has not published any data about genetic polymorphisms in the Brazilian population for these conjugation mechanisms to date.

Table 8 | Medicinal plant species listed in RENISUS with reported effects of on UGT levels.

\begin{tabular}{lcl}
\hline $\begin{array}{l}\text { Plant } \\
\text { species/Family }\end{array}$ & Effects on UGT levels & References \\
\hline $\begin{array}{l}\text { Allium sativum } \\
\text { (Aliaceae) }\end{array}$ & + & Ip and Lisk, 1997 \\
$\begin{array}{l}\text { Curcuma longa } \\
\text { (Zingiberaceae) }\end{array}$ & - & Naganuma et al., \\
\hline
\end{tabular}

+, Enzyme induction; -, Enzyme inhibition; NE, No Effect.

\section{EFFECTS OF PLANT SPECIES ON P-GLYCOPROTEIN (Pgp) ACTIVITY AND HERB-DRUG INTERACTION}

Drug-transporter proteins are known to allow xenobiotics to cross biological membranes, the most well-known one being Pgp. This protein plays a role as an efflux pump that pushes metabolites and drugs out of the cells which can result in pharmacokinetic alterations (Williamson et al., 2009). Some metabolites generated by the metabolism of herbal medicines can be pumped back to the lumen due to the activity of P-glycoprotein and hence, oral delivery can be compromised (Butterweck et al., 2004). Among the herbal medicines that are the object of this review, Achillea millefolium demonstrated inhibition of P-glycoprotein whereas Allium sativum activates the transporter (Table 9). Herbdrug interactions have already been reported on Pgp activity. For example, the HIV-protease inhibitor Saquinavir (substrate of CYP3A4) is absorbed in the intestine via P-glycoprotein. As garlic extracts may induce Pgp activity, the outcome of concomitant consumption of the herbal medicine with the essential drug could potentially reduce the bioavailability of the latter (Williamson et al., 2009).

Studies have shown that the gene ABCB1, which encodes Pgp, is very polymorphic and that the pharmacokinetics of several Pgp substrates could be significantly altered (Scheiner et al., 2010). REFARGEN has identified three ABCB1 polymorphisms in the Brazilian population: 1236T (rs1128503), 2677non G (rs2032582), and 3435T (rs1045642). Pharmacokinetic studies of drugs that affect the regulation of $\mathrm{ABCB} 1$, will help in the future in order to avoid herb-drug interactions on that level.

\section{PHARMACOVIGILANCE OF HERBAL MEDICINES}

The increasing consumption of herbal medicines in the world raises a concern about their rational use by the population. The WHO has recognized the potential risks of uncontrolled use of herbal medicines in conjunction with other medicines and hence, this Organization issued in 2004 the "Guidelines on safety monitoring of herbal medicines in pharmacovigilance systems." These guidelines indicate how member countries should include herbal medicines to an existent pharmacovigilance system to facilitate the exchange of information (WHO, 2004). After the establishment of ANVISA in 1999, efforts were concentrated on the creation of a national system of pharmacovigilance, and in 2001 the National Center for Drug Monitoring (CNMM) was founded. Notifications of ADRs in Brazil is currently made through an

Table 9 | Medicinal plant species listed in RENISUS with reported effects of on P-glycoprotein activity.

\begin{tabular}{lll}
\hline $\begin{array}{l}\text { Plant } \\
\text { species/Family }\end{array}$ & Effects on P-glycoprotein activity & References \\
\hline Achillea millefolium & - & Haidara et al., \\
(Asteraceae) & & 2006 \\
Allium sativum & + & Hajda et al., \\
(Aliaceae) & & 2010 \\
Curcuma longa & NE & Graber-Maier \\
(Zingiberaceae) & & et al., 2010
\end{tabular}

+ , Efflux increased; -, Efflux decreased. 
electronic system called NOTIVISA and these data come from three different sources: a "Sentinel Network," which provides information on adverse reactions related to the use of health products in hospitals, such as drugs, blood and hemoderivatives; pharmacies will report suspected cases of drug reactions (including herb-drug interactions); and a scheme of "Spontaneous Notifications" that can be made by any health professional registered into the electronic system (Mendes et al., 2008).

The number of ADRs notified by pharmacovigilance systems in the world until 2012 resulting from herb-drug interactions was 811, with Allium sativum, Mentha piperita, Zingiber officinale and Glycine max among the top 20 of the most commonly reported herbal medicines. Brazil was not included in the list of countries which have reported herb-drug interactions, demonstrating the difficulties in collection of such data by the pharmacovigilance system (Skalli and Soulaymani Bencheikh, 2012). Since the creation of NOTIVISA in 2008, there are no notifications of adverse reactions to herbal medicines, demonstrating that the new system created more obstacles to the users (Balbino and Dias, 2010).

Most of the problems related to the notification of ADRs due to herbal medicine consumption occur mainly because Practitioners and other health professionals are not well trained to detect the origin of the reaction. Besides, patients in general do not inform their use of herbal medicines and Physicians may not have sufficient knowledge about the effects of the phytomedicines in the body. Thus, educational campaigns should be utlilized in order to emphasize the rational use of medicinal plants and also to encourage health professionals to notify any adverse effect that might be a result of herb-drug interaction (Balbino and Dias, 2010).

\section{CONCLUSIONS}

In 2008 Brazil became a model country, clearly defining a positive list of herbal medicines considered "essential," and implementing an agenda to make possible the complete implementation of herbal medicines at a clinical level in the foreseeable future. This is a leading example within the current global trend toward the integration of herbal medicines into the healthcare system.

Our review highlights that little is known about native Brazilian plants. Most of the data is related to herbal medicines used worldwide, such as garlic, mint and devil's claw. We tried to interpret this in the context of the genetic makeup of the Brazilian population and how this may interact with essential drugs prescribed within the Brazilian healthcare system. It is evident that an enormous task should be undertaken to understand the pharmacokinetics of most local plant species.

Ensuring safety of herbal medicines goes beyond the interpretation of the preclinical or clinical evidence. Quality is also on the basis of safety and this is a challenging task in the field of Phytotherapy, with many drugs lacking identifiable active principles. Healthcare professionals and the public alike have to be well trained/informed in the use of the final medicinal product. Moreover, only a robust system of pharmacovigilance will help in the identification of relevant safety issues at a population level. These are not necessarily mirroring the preclinical and clinical data available.

At this stage, the preclinical pharmacokinetic profile of medicinal plants can only be evaluated with available data in literature.
Polymorphism studies in the Brazilian population have been a valuable source of information that can help with the assessment of ADRs and herb-drug interactions.

By tentatively exploring any potential interaction between herbal medicines and other essential medicines in the Brazilian system, we hope to open up future research to both bridge the gaps in knowledge and support future risk assessment of herbdrug combinations. Again, our results highlight that much more work is needed as over half of the medicinal plants lack data. Only after this is done can we start assessing the risk of herb-drug interactions when medicinal plants are taken with any essential drug.

Safety of herbal medicines finally lies in the hands of the patients. In this regard, healthcare professionals need proper training on how to advise the patient and the labeling of the product must anticipate further doubts when the patient cannot communicate with the professional.

\section{ACKNOWLEDGMENTS}

We would like to thank Science Without Borders (Brazilian scholarship scheme) for sponsoring the $\mathrm{PhD}$ student Andre Mazzari. A special thank you to Lindsay Reed and to John Rollafson for helping with the proofreading.

\section{REFERENCES}

Ajith, T. A., Hema, U., and Aswathy, M. S. (2007). Zingiber officinale Roscoe prevents acetaminophen-induced acute hepatotoxicity by enhancing hepatic antioxidant status. Food Chem. Toxicol. 45, 2267-2272. doi: 10.1016/j.fct.2007. 06.001

Al-Hashem, F. H. (2010). Gastroprotective effects of aqueous extract of Chamomilla recutita against ethanol-induced gastric ulcers. Saudi Med. J. 31, 1211-1216.

Alipour, M., Buonocore, C., Omri, A., Szabo, M., Pucaj, K., and Suntres, Z. E. (2013). Therapeutic effect of liposomal-N-acetylcysteine against acetaminophen-induced hepatotoxicity. J. Drug Target. 21, 466-473. doi: 10.3109/1061186X.2013.765443

Alpsoy, L., Sahin, H., and Karaman, S. (2011). Anti-oxidative and anti-genotoxic effects of methanolic extract of Mentha pulegium on human lymphocyte culture. Toxicol. Ind. Health 27, 647-654. doi: 10.1177/0748233710393402

Anoush, M., Eghbal, M. A., Fathiazad, F., Hamzeiy, H., and Kouzehkonani, N. S. (2009). The protective effects of garlic extract against acetaminophen-induced oxidative stress and glutathione depletion. Pak. J. Biol. Sci. 12, 765-771. doi: 10.3923/pjbs.2009.765.771

ANVISA. (2010). "Resolução-RDC 14, de 31 de Março de 2010. Estabelece os requisitos mínimos para o registro de medicamentos fitoterápicos,” ed A. N. d. V. Sanitária (Brasília: Brazilian Surveillance Agency). Available online at: http://portal2.saude.gov.br/saudelegis/LEG_NORMA_ PESQ_CONSULTA.CFM (Accessed June 01, 2013).

Anzenbacher, P., and Anzenbacherova, E. (2001). Cytochromes P450 and metabolism of xenobiotics. Cell. Mol. Life Sci. 58, 737-747. doi: 10.1007/ PL00000897

Atkinson, A. J. (2012). Principles of Clinical Pharmacology. San Diego, CA: Academic Press; Elsevier.

Balbino, E. E., and Dias, M. F. (2010). Farmacovigilância: um passo em direção ao uso racional de plantas medicinais e fitoterápicos. Rev. Bras. Farmacogn. 20, 992-1000. doi: 10.1590/S0102-695X2010005000031

Barbosa, A. C., Lajolo, F. M., and Genovese, M. I. (2011). Effect of free or proteinassociated soy isoflavones on the antioxidant status in rats. J. Sci. Food Agric. 91, 721-731. doi: 10.1002/jsfa.4242

Barbosa, L. C., Dias de Morais, M., de Paula, C. A., da Silva Ferreira, M. C., Jordao, A. A., Andrade e Silva, M. L., et al. (2012). Mikania glomerata Sprengel (Asteraceae) influences the mutagenicity induced by doxorubicin without altering liver lipid peroxidation or antioxidant levels. J. Toxicol. Environ. Health Part A 75, 1102-1109. doi: 10.1080/15287394.2012.697842 
Baxter, K., and Stockley, I. H. (2008). Stockley's Drug Interactions: A Source Book of Interactions, their Mechanisms, Clinical Importance, and Management. London; Chicago: Pharmaceutical Press.

Berka, K., Hendrychova, T., Anzenbacher, P., and Otyepka, M. (2011). Membrane position of ibuprofen agrees with suggested access path entrance to cytochrome P450 2C9 active site. J. Phys. Chem. A 115, 11248-11255. doi: 10.1021/jp20 $4488 \mathrm{j}$

Bhattacharjee, R., and Sil, P. C. (2006). The protein fraction of Phyllanthus niruri plays a protective role against acetaminophen induced hepatic disorder via its antioxidant properties. Phytother. Res. 20, 595-601. doi: 10.1002/ptr.1933

Budzinski, J. W., Foster, B. C., Vandenhoek, S., and Arnason, J. T. (2000). An in vitro evaluation of human cytochrome P450 3A4 inhibition by selected commercial herbal extracts and tinctures. Phytomedicine 7, 273-282. doi: 10.1016/S09447113(00)80044-6

Butterweck, V., Derendorf, H., Gaus, W., Nahrstedt, A., Schulz, V., and Unger, M. (2004). Pharmacokinetic herb-drug interactions: are preventive screenings necessary and appropriate? Planta Med. 70, 784-791. doi: 10.1055/s-2004-827223

Caira, M., and Ionescu, C. (2006). Drug Metabolism: Current Concepts. Dordrecht: Springer.

Cambria-Kiely, J. (2002). Effect of soy milk on warfarin efficacy. Ann. Pharmacother. 36A, 1893-1896. doi: 10.1345/aph.1C160

Caminal Homar, J. (2005). ¿Medicinas complementarias o alternativas? Un dilema para el sistema público. Atención Primaria 35, 389-391. doi: 10.1157/13074790

Chen, X. W., Serag, E. S., Sneed, K. B., Liang, J., Chew, H., Pan, S. Y., et al. (2011). Clinical herbal interactions with conventional drugs: from molecules to maladies. Curr. Med. Chem. 18, 4836-4850. doi: 10.2174/092986711797535317

Damasceno, D. C., Volpato, G. T., Calderon Ide, M., Aguilar, R., and Rudge, M. V. (2004). Effect of Bauhinia forficata extract in diabetic pregnant rats: maternal repercussions. Phytomedicine 11, 196-201. doi: 10.1078/0944-7113-00348

Dassprakash, M. V., Arun, R., Abraham, S. K., and Premkumar, K. (2012). In vitro and in vivo evaluation of antioxidant and antigenotoxic potential of Punica granatum leaf extract. Pharm. Biol. 50, 1523-1530. doi: 10.3109/13880209.2012.689771

Faria, A., Monteiro, R., Azevedo, I., and Calhau, C. (2007a). Pomegranate juice effects on cytochrome P450S expression: in vivo studies. J. Med. Food 10, 643-649. doi: 10.1089/jmf.2007.403

Faria, A., Monteiro, R., Mateus, N., Azevedo, I., and Calhau, C. (2007b). Effect of pomegranate (Punica granatum) juice intake on hepatic oxidative stress. Eur. J. Nutr. 46, 271-278. doi: 10.1007/s00394-007-0661-z

Feijó, A. M., Bueno, M. E. N., Ceolin, T., Linck, C. L., Schwartz, E., Lange, C., et al. (2012). Plantas medicinais utilizadas por idosos com diagnóstico de Diabetes mellitus no tratamento dos sintomas da doença. Rev. Bras. Plant. Med. 14, 50-56. doi: 10.1590/S1516-05722012000100008

Foster, B. C., Foster, M. S., Vandenhoek, S., Krantis, A., Budzinski, J. W., Arnason, J. T., et al. (2001). An in vitro evaluation of human cytochrome P450 3A4 and P-glycoprotein inhibition by garlic. J. Pharm. Pharm. Sci. 4, 176-184.

Gibson, G. G., and Skett, P. (2001). Introduction to Drug Metabolism. London: Nelson Thornes.

Gonzalez, H. M., Romero, E. M., Peregrina, A. A., de J Chávez, T., Escobar-Islas, E., Lozano, F., et al. (2003). CYP2C19- and CYP3A4-dependent omeprazole metabolism in West Mexicans. J. Clin. Pharmacol. 43, 1211-1215. doi: 10.1177/0091270003258170

Graber-Maier, A., Buter, K. B., Aeschlimann, J., Bittel, C., Kreuter, M., Drewe, J., et al. (2010). Effects of Curcuma extracts and curcuminoids on expression of P-glycoprotein and cytochrome P450 3A4 in the intestinal cell culture model LS180. Planta Med. 76, 1866-1870. doi: 10.1055/s-0030-1249980

Guillemette, C. (2003). Pharmacogenomics of human UDPglucuronosyltransferase enzymes. Pharmacogenomics J. 3, 136-158. doi: 10.1038/sj.tpj.6500171

Gwilt, P. R., Lear, C. L., Tempero, M. A., Birt, D. D., Grandjean, A. C., Ruddon, R. W., et al. (1994). The effect of garlic extract on human metabolism of acetaminophen. Cancer Epidemiol. Biomarkers Prev. 3, 155-160.

Haidara, K., Zamir, L., Shi, Q. W., and Batist, G. (2006). The flavonoid Casticin has multiple mechanisms of tumor cytotoxicity action. Cancer Lett. 242, 180-190. doi: 10.1016/j.canlet.2005.11.017

Hajda, J., Rentsch, K. M., Gubler, C., Steinert, H., Stieger, B., and Fattinger, K. (2010). Garlic extract induces intestinal P-glycoprotein, but exhibits no effect on intestinal and hepatic CYP3A4 in humans. Eur. J. Pharm. Sci. 41, 729-735. doi: 10.1016/j.ejps.2010.09.016
Hanley, M. J., Masse, G., Harmatz, J. S., Court, M. H., and Greenblatt, D. J. (2012). Pomegranate juice and pomegranate extract do not impair oral clearance of flurbiprofen in human volunteers: divergence from in vitro results. Clin. Pharmacol. Ther. 92, 651-657. doi: 10.1038/clpt.2012.170

Hari Kumar, K. B., and Kuttan, R. (2006). Inhibition of drug metabolizing enzymes (cytochrome P450) in vitro as well as in vivo by Phyllanthus amarus SCHUM and THONN. Biol. Pharm. Bull. 29, 1310-1313. doi: 10.1248/bpb.29.1310

Hau, D. K., Gambari, R., Wong, R. S., Yuen, M. C., Cheng, G. Y., Tong, C. S., et al. (2009). Phyllanthus urinaria extract attenuates acetaminophen induced hepatotoxicity: involvement of cytochrome P450 CYP2E1. Phytomedicine 16, 751-760. doi: 10.1016/j.phymed.2009.01.008

He, S. M., Li, C. G., Liu, J. P., Chan, E., Duan, W., and Zhou, S. F. (2010). Disposition pathways and pharmacokinetics of herbal medicines in humans. Curr. Med. Chem. 17, 4072-4113. doi: 10.2174/092986710793205336

Heck, A. M., DeWitt, B. A., and Lukes, A. L. (2000). Potential interactions between alternative therapies and warfarin. Am. J. Health Syst. Pharm. 57, 1221-1227; quiz 1228-1230.

Hegazy, S. K., El-Bedewy, M., and Yagi, A. (2012). Antifibrotic effect of aloe vera in viral infection-induced hepatic periportal fibrosis. World J. Gastroenterol. 18, 2026-2034. doi: 10.3748/wjg.v18.i17.2026

Ho, B. E., Shen, D. D., McCune, J. S., Bui, T., Risler, L., Yang, Z., et al. (2010). Effects of garlic on cytochromes P450 2C9- and 3A4-mediated drug metabolism in human hepatocytes. Sci. Pharm. 78, 473-481. doi: 10.3797/scipharm.1002-11

Hu, Z., Yang, X., Ho, P. C., Chan, S. Y., Heng, P. W., Chan, E., et al. (2005). Herb-drug interactions: a literature review. Drugs 65, 1239-1282. doi: 10.2165/00003495-200565090-00005

Ionescu, C., and Caira, M. R. (2005). Drug Metabolism: Current Concepts. Dordrecht: Springer.

Ip, C., and Lisk, D. J. (1997). Modulation of phase I and phase II xenobioticmetabolizing enzymes by selenium-enriched garlic in rats. Nutr. Cancer 28, 184-188. doi: 10.1080/01635589709514573

Joy, M. S., Dornbrook-Lavender, K., Blaisdell, J., Hilliard, T., Boyette, T., Hu, Y., et al. (2009). CYP2C9 genotype and pharmacodynamic responses to losartan in patients with primary and secondary kidney diseases. Eur. J. Clin. Pharmacol. 65, 947-953. doi: 10.1007/s00228-009-0707-7

Kaithwas, G., Dubey, K., and Pillai, K. K. (2011). Effect of aloe vera (Aloe barbadensis Miller) gel on doxorubicin-induced myocardial oxidative stress and calcium overload in albino rats. Indian J. Exp. Biol. 49, 260-268.

Karuna, R., Reddy, S. S., Baskar, R., and Saralakumari, D. (2009). Antioxidant potential of aqueous extract of Phyllanthus amarus in rats. Indian J. Pharmacol. 41, 64-67. doi: 10.4103/0253-7613.51342

Kimura, Y., Ito, H., and Hatano, T. (2010). Effects of mace and nutmeg on human cytochrome P450 3A4 and 2C9 activity. Biol. Pharm. Bull. 33, 1977-1982. doi: 10.1248/bpb.33.1977

Kohlrausch, F. B., Carracedo, A., and Hutz, M. H. (2014). Characterization of CYP1A2, CYP2C19, CYP3A4 and CYP3A5 polymorphisms in South Brazilians. Mol. Biol. Rep. 41, 1453-1460. doi: 10.1007/s11033-013-2990-8

Komperda, K. E. (2009). Potential interaction between pomegranate juice and warfarin. Pharmacotherapy 29, 1002-1006. doi: 10.1592/phco.29.8.1002

Kuehl, G. E., Lampe, J. W., Potter, J. D., and Bigler, J. (2005). Glucuronidation of nonsteroidal anti-inflammatory drugs: identifying the enzymes responsible in human liver microsomes. Drug Metab. Dispos. 33, 1027-1035. doi: 10.1124/dmd.104.002527

Kumar, K. B., and Kuttan, R. (2004). Protective effect of an extract of Phyllanthus amarus against radiation-induced damage in mice. J. Radiat. Res. 45, 133-139. doi: 10.1269/jrr.45.133

Kumar, K. B., and Kuttan, R. (2005). Chemoprotective activity of an extract of Phyllanthus amarus against cyclophosphamide induced toxicity in mice. Phytomedicine 12, 494-500. doi: 10.1016/j.phymed.2004.03.009

Le Bon, A. M., Vernevaut, M. F., Guenot, L., Kahane, R., Auger, J., Arnault, I., et al. (2003). Effects of garlic powders with varying alliin contents on hepatic drug metabolizing enzymes in rats. J. Agric. Food Chem. 51, 7617-7623. doi: $10.1021 /$ jf0346758

Lee, K. J., You, H. J., Park, S. J., Kim, Y. S., Chung, Y. C., Jeong, T. C., et al. (2001). Hepatoprotective effects of Platycodon grandiflorum on acetaminopheninduced liver damage in mice. Cancer Lett. 174, 73-81. doi: 10.1016/S03043835(01)00678-4

Liu, A. C., Zhao, L. X., and Lou, H. X. (2013). Curcumin alters the pharmacokinetics of warfarin and clopidogrel in Wistar rats but has no effect on 
anticoagulation or antiplatelet aggregation. Planta Med. 79, 971-977. doi: 10.1055/s-0032-1328652

Lopez Galera, R. M., Ribera Pascuet, E., Esteban Mur, J. I., Montoro Ronsano, J. B., and, Juarez Gimenez, J. C. (2008). Interaction between cat's claw and protease inhibitors atazanavir, ritonavir and. Eur. J. Clin. Pharmacol. 64, 1235-1236. doi: 10.1007/s00228-008-0551-1

Maity, S., Nag, N., Chatterjee, S., Adhikari, S., and Mazumder, S. (2013). Bilirubin clearance and antioxidant activities of ethanol extract of Phyllanthus amarus root in phenylhydrazine-induced neonatal jaundice in mice. J. Physiol. Biochem. 69, 467-476. doi: 10.1007/s13105-013-0234-y

Manjrekar, A. P., Jisha, V., Bag, P. P., Adhikary, B., Pai, M. M., Hegde, A., et al. (2008). Effect of Phyllanthus niruri Linn. treatment on liver, kidney and testes in CCl4 induced hepatotoxic rats. Indian J. Exp. Biol. 46, 514-520.

Markowitz, J. S., Devane, C. L., Chavin, K. D., Taylor, R. M., Ruan, Y., and Donovan, J. L. (2003). Effects of garlic (Allium sativum L.) supplementation on cytochrome P450 2D6 and 3A4 activity in healthy volunteers. Clin. Pharmacol. Ther. 74, 170-177. doi: 10.1016/S0009-9236(03)00148-6

Mendes, E. V. (2013). 25 anos do Sistema Único de Saúde: resultados e desafios. Estud. Av. 27, 27-34. doi: 10.1590/S0103-40142013000200003

Mendes, M. C. P., Pinheiro, R. O., Avelar, K. E. S., Teixeira, J. L., and sa Silve, G. M. S. (2008). Pharmacovigilance history in Brazil. Brazil. J. Pharm. 89, 246-251.

Miccadei, S., Di Venere, D., Cardinali, A., Romano, F., Durazzo, A., Foddai, M. S., et al. (2008). Antioxidative and apoptotic properties of polyphenolic extracts from edible part of artichoke (Cynara scolymus L.) on cultured rat hepatocytes and on human hepatoma cells. Nutr. Cancer 60, 276-283. doi: 10.1080/01635580801891583

Mo, S. L., Zhou, Z. W., Yang, L. P., Wei, M. Q., and Zhou, S. F. (2009). New insights into the structural features and functional relevance of human cytochrome P450 2C9. Part I. Curr. Drug Metab. 10, 1075-1126. doi: 10.2174/138920009790820129

Modarai, M., Suter, A., Kortenkamp, A., and Heinrich, M. (2011). The interaction potential of herbal medicinal products: a luminescence-based screening platform assessing effects on cytochrome P450 and its use with devil's claw (Harpagophyti radix) preparations. J. Pharm. Pharmacol. 63, 429-438. doi: 10.1111/j.2042-7158.2010.01235.x

Naaz, F., Javed, S., and Abdin, M. Z. (2007). Hepatoprotective effect of ethanolic extract of Phyllanthus amarus Schum. et Thonn. on aflatoxin B1-induced liver damage in mice. J. Ethnopharmacol. 113, 503-509. doi: 10.1016/j.jep.2007.07.017

Naganuma, M., Saruwatari, A., Okamura, S., and Tamura, H. (2006). Turmeric and curcumin modulate the conjugation of 1-naphthol in Caco-2 cells. Biol. Pharm. Bull. 29, 1476-1479. doi: 10.1248/bpb.29.1476

Neafsey, P., Ginsberg, G., Hattis, D., Johns, D. O., Guyton, K. Z., and Sonawane, B. (2009). Genetic polymorphism in CYP2E1: Population distribution of CYP2E1 activity. J. Toxicol. Environ. Health B Crit. Rev. 12, 362-388. doi: 10.1080/10937400903158359

Nielsen, K. K., Flinois, J. P., Beaune, P., and Brosen, K. (1996). The biotransformation of clomipramine in vitro, identification of the cytochrome P450s responsible for the separate metabolic pathways. J. Pharmacol. Exp. Ther. 277, 1659-1664.

Nogueira, N. P., Reis, P. A., Laranja, G. A., Pinto, A. C., Aiub, C. A., Felzenszwalb, I., et al. (2011). In vitro and in vivo toxicological evaluation of extract and fractions from Baccharis trimera with anti-inflammatory activity. J. Ethnopharmacol. 138, 513-522. doi: 10.1016/j.jep.2011.09.051

Patel, J. R., Tripathi, P., Sharma, V., Chauhan, N. S., and Dixit, V. K. (2011). Phyllanthus amarus: ethnomedicinal uses, phytochemistry and pharmacology: a review. J. Ethnopharmacol. 138, 286-313. doi: 10.1016/j.jep.2011.09.040

Potrich, F. B., Allemand, A., da Silva, L. M., Dos Santos, A. C., Baggio, C. H., Freitas, C. S., et al. (2010). Antiulcerogenic activity of hydroalcoholic extract of Achillea millefolium L.: involvement of the antioxidant system. J. Ethnopharmacol. 130, 85-92. doi: 10.1016/j.jep.2010.04.014

Preethi, K. C., and Kuttan, R. (2009). Hepato and reno protective action of Calendula officinalis L. flower extract. Indian J. Exp. Biol. 47, 163-168.

Rabelo, A. F., Guedes, M. M., Tome Ada, R., Lima, P. R., Maciel, M. A., Lira, S. R., et al. (2010). Vitamin E ameliorates high dose trans-dehydrocrotoninassociated hepatic damage in mice. Nat. Prod. Commun. 5, 523-528.

Rahman, S., and Singhal, K. (2002). Problems in Pharmacovigilance of Medicinal Products of Herbal Origin and Means to Minimize Them. Uppsala: Uppsalla Reports January Suplement.
Rajkapoor, B., Jayakar, B., Murugesh, N., and Sakthisekaran, D. (2006). Chemoprevention and cytotoxic effect of Bauhinia variegata against $\mathrm{N}$-nitrosodiethylamine induced liver tumors and human cancer cell lines. J. Ethnopharmacol. 104, 407-409. doi: 10.1016/j.jep.2005.08.074

Ramsay, N. A., Kenny, M. W., Davies, G., and Patel, J. P. (2005). Complimentary and alternative medicine use among patients starting warfarin. Br. J. Haematol. 130, 777-780. doi: 10.1111/j.1365-2141.2005.05689.x

Ratheesh, M., Shyni, G. L., Sindhu, G., and Helen, A. (2011). Inhibitory effect of Ruta graveolens L. on oxidative damage, inflammation and aortic pathology in hypercholesteromic rats. Exp. Toxicol. Pathol. 63, 285-290. doi: 10.1016/j.etp.2010.01.007

Raza, H., Ahmed, I., John, A., and Sharma, A. K. (2000). Modulation of xenobiotic metabolism and oxidative stress in chronic streptozotocin-induced diabetic rats fed with Momordica charantia fruit extract. J. Biochem. Mol. Toxicol. 14, 131-139. doi: 10.1002/(SICI) 1099-0461(2000)14:3<131::AID-JBT2>3. $0 . \mathrm{CO} ; 2-\mathrm{Q}$

Raza, H., Ahmed, I., Lakhani, M. S., Sharma, A. K., Pallot, D., and Montague, W. (1996). Effect of bitter melon (Momordica charantia) fruit juice on the hepatic cytochrome P450-dependent monooxygenases and glutathione S-transferases in streptozotocin-induced diabetic rats. Biochem. Pharmacol. 52, 1639-1642. doi: 10.1016/S0006-2952(96)00526-6

Reddy, G. D., Reddy, A. G., Rao, G. S., and Kumar, M. V. (2012). Pharmacokinetic interaction of garlic and atorvastatin in dyslipidemic rats. Indian J. Pharmacol. 44, 246-252. doi: 10.4103/0253-7613.93860

Ribeiro, A. Q., Leite, J. P. V., and Dantas-Barros, A. M. (2005). Perfil de utilização de fitoterápicos em farmácias comunitárias de Belo Horizonte sob a influência da legislação nacional. Rev. Bras. Farmacogn. 15, 65-70. doi: 10.1590/S0102695X2005000100014

Rong, S., Zhao, Y., Bao, W., Xiao, X., Wang, D., Nussler, A. K., et al. (2012). Curcumin prevents chronic alcohol-induced liver disease involving decreasing ROS generation and enhancing antioxidative capacity. Phytomedicine 19, 545-550. doi: 10.1016/j.phymed.2011.12.006

Rossini, A., Rapozo, D. C., Amorim, L. M., Macedo, J. M., Medina, R., Neto, J. F., et al. (2002). Frequencies of GSTM1, GSTT1, and GSTP1 polymorphisms in a Brazilian population. Genet. Mol. Res. 1, 233-240.

Salama, S. M., Abdulla, M. A., AlRashdi, A. S., Ismail, S., Alkiyumi, S. S., and Golbabapour, S. (2013). Hepatoprotective effect of ethanolic extract of Curcuma longa on thioacetamide induced liver cirrhosis in rats. BMC Complement. Altern. Med. 13:56. doi: 10.1186/1472-6882-13-56

Saúde, S. Ú. D. (2009). Relação Nacional de Plantas Medicinais de Interesse ao SUS (RENISUS). Brazil: Ministerio da Saude.

Saúde, S. Ú. D. (2010). Relação de Medicamentos Essenciais (RENAME). Brazil: Ministerio da Saude.

Scheiner, M. A., Damasceno, A. M., and Maia, R. C. (2010). ABCB1 single nucleotide polymorphisms in the Brazilian population. Mol. Biol. Rep. 37, 111-118. doi: 10.1007/s11033-009-9547-x

Scripture, C. D., and Pieper, J. A. (2001). Clinical pharmacokinetics of fluvastatin. Clin. Pharmacokinet. 40, 263-281. doi: 10.2165/00003088-200140040-00003

Sharma, A., Sharma, M. K., and Kumar, M. (2007). Protective effect of Mentha piperita against arsenic-induced toxicity in liver of Swiss albino mice. Basic Clin. Pharmacol. Toxicol. 100, 249-257. doi: 10.1111/j.1742-7843.2006.00030.x

Shen, B., Yu, J., Wang, S., Chu, E. S., Wong, V. W., Zhou, X., et al. (2008). Phyllanthus urinaria ameliorates the severity of nutritional steatohepatitis both in vitro and in vivo. Hepatology 47, 473-483. doi: 10.1002/hep.22039

Shon, Y. H., and Nam, K. S. (2004). Inhibition of cytochrome P450 isozymes and ornithine decarboxylase activities by polysaccharides from soybeans fermented with Phellinus igniarius or Agrocybe cylindracea. Biotechnol. Lett. 26, 159-163. doi: 10.1023/B:BILE.0000012900.63039.10

Sies, H., and Ketterer, B. (1988). Glutathione Conjugation. Cornwall: Academic Press.

Silveira, P. F., Bandeira, M. A. M., and Arrais, P. S. D. (2008). Farmacovigilância e reações adversas às plantas medicinais e fitoterápicos: uma realidade. Rev. Bras. Farmacogn. 18, 618-626. doi: 10.1590/S0102-695X2008000400021

Simões, C. U. M. O., and Mariot, A. (2003). Farmacognosia: Da Planta ao Medicamento. Florianópolis; Porto Alegre: Editora da UFSC; Editora da UFRGS.

Singh, B., Kale, R. K., and Rao, A. R. (2004). Modulation of antioxidant potential in liver of mice by kernel oil of cashew nut (Anacardium occidentale) and its lack of tumour promoting ability in DMBA induced skin papillomagenesis. Indian J. Exp. Biol. 42, 373-377. 
Skalli, S., and Soulaymani Bencheikh, R. (2012). Safety monitoring of herb-drug interactions: a component of pharmacovigilance. Drug Saf. 35, 785-791. doi: $10.1007 /$ BF03261975

Suarez-Kurtz, G. (2004). Pharmacogenomics in admixed populations: the Brazilian pharmacogenetics/pharmacogenomics network-REFARGEN. Pharmacogenomics J. 4, 347-348. doi: 10.1038/sj.tpj.6500287

Suarez-Kurtz, G. (2005). Pharmacogenomics in admixed populations. Trends Pharmacol. Sci. 26, 196-201. doi: 10.1016/j.tips.2005.02.008

Subehan, Usia, T., Iwata, H., Kadota, S., and Tezuka, Y. (2006). Mechanismbased inhibition of CYP3A4 and CYP2D6 by Indonesian medicinal plants. J. Ethnopharmacol. 105, 449-455. doi: 10.1016/j.jep.2005.12.001

Subehan, Zaidi, S. F., Kadota, S., and Tezuka, Y. (2007). Inhibition on human liver cytochrome P450 3A4 by constituents of fennel (Foeniculum vulgare): identification and characterization of a mechanism-based inactivator. J. Agric. Food Chem. 55, 10162-10167. doi: 10.1021/jf0713253

SUS. (2009). Relação Nacional de Plantas Medicinais de Interesse ao SUS (RENISUS). Brazil.

SUS. (2010). Relação de Medicamentos Essenciais (RENAME). Brazil.

Tandon, N., Roy, M., Roy, S., and Gupta, N. (2012). Protective effect of psidium guajava in arsenic-induced oxidative stress and cytological damage in rats. Toxicol. Int. 19, 245-249. doi: 10.4103/0971-6580.103658

Thapliyal, R., Deshpande, S. S., and Maru, G. B. (2002). Mechanism(s) of turmericmediated protective effects against benzo(a)pyrene-derived DNA adducts. Cancer Lett. 175, 79-88. doi: 10.1016/S0304-3835(01)00675-9

Trojan-Rodrigues, M., Alves, T. L., Soares, G. L., and Ritter, M. R. (2012). Plants used as antidiabetics in popular medicine in Rio Grande do Sul, southern Brazil. J. Ethnopharmacol. 139, 155-163. doi: 10.1016/j.jep.2011. 10.034

Unger, M., and Frank, A. (2004). Simultaneous determination of the inhibitory potency of herbal extracts on the activity of six major cytochrome P450 enzymes using liquid chromatography/mass spectrometry and automated online extraction. Rapid Commun. Mass Spectrom. 18, 2273-2281. doi: 10.1002/ $\mathrm{rcm} .1621$

Usia, T., Iwata, H., Hiratsuka, A., Watabe, T., Kadota, S., and Tezuka, Y. (2006). CYP3A4 and CYP2D6 inhibitory activities of Indonesian medicinal plants. Phytomedicine 13, 67-73. doi: 10.1016/j.phymed.2004.06.022

von Moltke, L. L., Greenblatt, D. J., Duan, S. X., Schmider, J., Wright, C. E., Harmatz, J. S., et al. (1997). Human cytochromes mediating Ndemethylation of fluoxetine in vitro. Psychopharmacology (Berl). 132, 402-407. doi: $10.1007 / \mathrm{s} 002130050362$

Wang, B., and Zhou, S. F. (2009). Synthetic and natural compounds that interact with human cytochrome P450 1A2 and implications in drug development. Curr. Med. Chem. 16, 4066-4218. doi: 10.2174/092986709789378198

Wang, H., Song, K., Chen, Z., and Yu, Y. (2013). Poor metabolizers at the cytochrome P450 2C19 loci is at increased risk of developing cancer in Asian populations. PLoS ONE 8:e73126. doi: 10.1371/journal.pone. 0073126

W.E.C.o.t.S.a.U.o.E. Medicines. (2012). The Selection and Use of Essential Medicines: Report of the WHO Expert Committee, 2011 (Including the 17th WHO Model List of Essential Medicines and the 3rd WHO Model List of Essential Medicines for Children). Geneva: World Health Organization.

Weinshilboum, R. (1988). Pharmacogenetics of methylation: relationship to drug metabolism. Clin. Biochem. 21, 201-210. doi: 10.1016/S0009-9120(88)80002-X

WHO. (2004). Guidelines on Safety Monitoring of Herbal Medicines in Pharmacovigilance Systems. Geneva: World Health Organization.

WHO. (2012). The Selection and Use of Essential Medicines: Report of the WHO Expert Committee, 2011 (Including the 17th WHO Model List of Essential Medicines and the 3rd WHO Model List of Essential Medicines for Children). Geneva: World Health Organization.

WHO. (2013). WHO Model List of Essential Medicines. Geneva: World Health Organization.

Williamson, E. M., Driver, S., and Baxter, K. (2009). Stockley's Herbal Medicines Interactions: A Guide to the Interactions of Herbal Medicines, Dietary Supplements and Nutraceuticals with Conventional Medicines. London; Chicago: Pharmaceutical Press.

Zhang, Z. G., Lu, X. B., Xiao, L., Tang, L., Zhang, L. J., Zhang, T., et al. (2012). Antioxidant effects of the Uygur herb, Foeniculum Vulgare Mill, in a rat model of hepatic fibrosis. Zhonghua Gan Zang Bing Za Zhi 20, 221-226. doi: 10.3760/ cma.j.issn.1007-3418.2012.03.017

Zhou, S. F., Liu, J. P., and Chowbay, B. (2009). Polymorphism of human cytochrome P450 enzymes and its clinical impact. Drug Metab. Rev. 41, 89-295. doi: $10.1080 / 03602530902843483$

Conflict of Interest Statement: The authors declare that the research was conducted in the absence of any commercial or financial relationships that could be construed as a potential conflict of interest.

Received: 30 April 2014; paper pending published: 27 May 2014; accepted: 20 June 2014; published online: 09 July 2014.

Citation: Mazzari ALDA and Prieto JM (2014) Herbal medicines in Brazil: pharmacokinetic profile and potential herb-drug interactions. Front. Pharmacol. 5:162. doi: 10.3389/fphar.2014.00162

This article was submitted to Ethnopharmacology, a section of the journal Frontiers in Pharmacology.

Copyright (c) 2014 Mazzari and Prieto. This is an open-access article distributed under the terms of the Creative Commons Attribution License (CC BY). The use, distribution or reproduction in other forums is permitted, provided the original author(s) or licensor are credited and that the original publication in this journal is cited, in accordance with accepted academic practice. No use, distribution or reproduction is permitted which does not comply with these terms. 